\title{
Student questioning in literature circles: An investigation of forms of questioning among ELT students
}

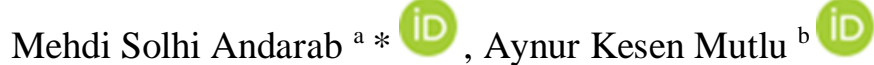 \\ ${ }^{a}$ Istanbul Medipol University, Istanbul 34815, Turkey \\ ${ }^{b}$ Istanbul Medipol University, Istanbul 34815, Turkey
}

APA Citation:

Solhi Andarab, M., \& Kesen Mutlu, A. (2019). Student questioning in literature circles: An investigation of forms of questioning among ELT students. Journal of Language and Linguistic Studies, 15(1), 326-338.

Submission Date:23/11/2018

Acceptance Date:15/03/2019

\begin{abstract}
In this study, different types of questions (i.e., choice, product, process, metaproces) being asked by two groups of ELT freshmen while conducting literature circles, one of the most useful ways to activate cooperative learning among the students, were put under a close scrutiny. The first group comprised of thirty-seven students who had directly passed the proficiency exam of the university, while the latter consisted of the thirty-five students who studied at the preparatory school for a year. The different types of questions posed by the questioners in each circle were analyzed. According to the findings, there was no significant difference between the students who studied at the English preparatory school for a year, and the ones who directly passed the proficiency exam of the university. Nor did gender play a significant role in the participants' preference for questioning types. In both groups, product questions were the most frequent type of questioning, while metaprocess questions remained the least used types in both literature circles.
\end{abstract}

(C) 2019 JLLS and the Authors - Published by JLLS.

Keywords: Choice; product; process; metaprocess questions; literature circle

\section{Introduction}

Enhancing learning opportunities in the classroom by involving learners in the process of learning, and shifting responsibility to them has often been emphasized as a key ingredient of fruitful educative methods by a large number of scholars (Bajrami, 2015; Cook-Sather, 2010; Kumaravadivelu, 2003; Chatelier \& Rudolph, 2018). Questioning is a fundamental aspect of language learning in the classroom, and triggering meaningful interaction between students relies on asking the right type of questions. Harlen and Qualter (2004) assert that questioning is a fecund means of enhancing students' analytical and communicative capacities. Doherty (2017, P. 1) similarly believes that asking questions is an integral part of classroom and emphasizes that questioning is "essential to every teacher's pedagogical repertoire". In fact, questioning has the potential to engage learners in the learning process and opens up opportunities for learners to ask questions themselves. In a classroom setting, Hugh Mehan (1979, as

\footnotetext{
${ }^{*}$ Corresponding author. Tel.: +90-216-681-5100/1717

E-mail address: solhi.mehdi@gmail.com
} 
cited in Kumaravadivelu, 2003) categorizes four types of questions that are likely to occur: choice, product, process, and metaprocess.

- Choice questions require learners to agree or disagree with a statement, and/or choose a yes or no response from a given list. To exemplify, the learners might be asked whether they would prefer tea or coffee, or whether they go to the gym after the classes.

- Product questions, meanwhile, aim to elicit a factual response from learners such as a name or a place. An example of such kind of questioning would be drawing some response about where the learners live, what their favorite sport is, and so on.

- Process questions inquire about the learners' opinions or interpretations. Process questions in the classroom most commonly revolve around asking a learner what opinion they hold on a given subject.

- Metaprocess questions go further, by asking for the reasoning behind the learner's thought. Therefore, they ask the basis on which a belief rests. They can also be formulated to elicit from someone, the rule or procedure by which they may arrive at the reasoning or remembered answer. Asking the question of how, is a typical type of metaprocess questioning featuring in classroom interactions.

Kumaravadivelu (2003) forwards the point that despite the common and wide utilization of choice and product questioning types in language teaching classrooms, process and metaprocess types of questioning are inherently more likely to pave the way for negotiated interaction among learners, and, consequently, have more potential to generate learning opportunities. He indicates that process/metaprocess, or referential questions, have the considerable potential to promote learning opportunities in the classroom, and to ensure exchange of information. Simply put, they have endowments to obtain new and unpredictable pieces of information from the learners. In addition, such kinds of questions can potentially incite them to activate their reasoning skills, while choice and product questions make them just passively extract some already known information from memory. One of the observations in Kumaravadivelu's Beyond Methods: Macrostrategies for Language Teaching (2003) indicates that by asking referential questions, the teacher has succeeded in promoting negotiated interaction, even in classrooms where learners possess very limited linguistic and communicative ability.

\subsection{Student questioning}

Apparently, despite the myriad number of studies addressing teacher questioning (e.g., Chin, 2007; Heritage \& Heritage, 2013; Qashoa, 2012; Shomoossi, 2004; Wu, 1993), learners' practice of questioning has been grossly neglected in classroom research. In a study by Graesser and Person (1994), student questioning was reported as amounting to an average of only one question per week. Graesser and Person (1994) believe that questioning in the classroom needs to be practiced by both instructors and students. Echoing Graesser and Person, Willis and Willis (2007) also criticize the current status of questioning in the classroom. In fact, as Almeida \& Neri-de-Souza (2010) put forward, in a traditional context of learning, it is the teacher who poses the questions and the students who answer. However, the reality is that learning does not take place until learners can formulate their own questions. In a nutshell, students' questions play a fundamental role in meaningful learning. Almeida \& Neri-de-Souza (2010) add that student questioning is of significant importance to the process of teaching and learning. This is due to the fact that student questioning can have various functions: nurturing a culture of questioning and critical thinking; enhancing conceptual understanding; fostering classroom interaction; and encouraging autonomous learning. Almeida \& Neri-de-Souza (2010, p. 7) maintain that in today's world, "the development of the critical, reflexive and creative thinking" should be the focus of secondary 
teaching so as to equip students with the tools required to "become active and autonomous citizens, as well as lifelong learners", continuing to conclude that "(t)hese competencies can be achieved through the stimulation of students' active learning, namely through questioning". In fact, the fulfillment of language instructors' pedagogic intentions in conjunction with the enrichment of learners' potential to promote improved interactions and the attainment of miscellaneous social and academic aims, according to Rezvani and Sayyadi (2015), are closely connected to the instructors' and students' practice of questioning in classroom discourse, rather than solely the instructors' questioning. However, instructors' over-reliance on questioning as the main pedagogical practice to elicit responses from students has considerably constrained student questioning. For example, in an attempt to examine the classroom behavior of a group of elementary instructors many years ago, Floyd (1960) indicated that that the teacher questioning exceeded $93 \%$ of classroom questions. According to Hastings (2003), teachers ask up to two questions every minute. This can rise to up to 400 questions in a day; approximately $70000 \mathrm{a}$ year, or two to three million in the course of a career! However, Almeida and Neri de Souza (2010, p. 4) believe that even if teachers ask a large number of questions in class, the questions posed are consistently of the same kind. They typically ask "low level questions, requiring mainly memory".

As that is evident, a great number of scholars point to the undeniable place of asking questions in the classroom, and define it is one of the most popular modes of teaching (Arslan, 2006). Such figures indicate the pivotal role of questioning in classroom interactions. However, there seems to be a gap in exploring the exact efficiency of questioning in the learning process. Over the last years, some emphasis has been shifted to allocating the responsibility of questioning onto students rather than their teachers and has indicated that this contributes to student learning (Almeida et al., 2008; Coutinho \& Almeida, 2014; Martinho, Almeida \& Teixeira-Dias, 2012). According to Graesser and Person (1994, p. 2), student questioning in the classroom is "very infrequent and unsophisticated". Despite the low frequency of the questions asked by the students, students' questions are believed to play a high role in learning science (Almeida et al., 2008; Graesser \& Olde, 2003), and to activate a higher level of reasoning among students (Zoller et al. 1987).

\subsection{Literature circle}

Forming literature circles (i.e., groups) in the classroom is one of the most useful ways to activate cooperative learning among the students, and to enhance critical thinking of them as they read and discuss texts. Collaborative approaches are key to allowing learners to reshape and add to their understanding as they construct meaning with other readers. Put simply, literature circles lead learners to a deeper understanding of what they read through structured discussion. In a literature circle, a number of roles are assigned to different individuals. Culture-connector, questioner, vocabulary builder, character analyzer, and summarizer are just some of the roles that the individuals in a circle may take on while analyzing a reading text. Questioner, or discussion director, is a role taken on by a member of a literature circles in which one is expected to develop a list of questions from the text aimed at engaging students in conversations and debates.

\subsection{Research questions}

Despite the educational significance attributed to students questioning, it seems that little research has been conducted in order to investigate student questioning in tertiary education. In this study, different types of questions being asked by two groups of ELT freshmen while conducting literature circles in the classroom have been put under close scrutiny in an attempt to investigate whether the questioning types (i.e., product, choice, process, and metaprocess) of the students who have directly passed the proficiency exam are different from the ones who have studied at the preparatory school before they enter their main department of study. This research has also sought to discover whether 
gender plays a significant role in the preference for asking certain question types. Hence, the following research questions were addressed in this study:

Q1: Are the questioning types of the students who have directly passed the proficiency exam are different from the ones who have studied at the preparatory school?

Q2: Does gender play a significant role in the participants' preference for questioning types?

\section{Method}

\subsection{Participants}

The individuals participating in this study included 72 English as a Foreign Language (EFL) learners aged 18-27. They were the freshmen studying in two different classes at ELT department of a private university in Turkey. The first group was comprised of thirty-seven students who had directly passed the English language proficiency exam to enter university, while the latter consisted of the thirty-five students who studied at the preparatory school of the university for a year before having passed the proficiency exam. Both groups had achieved the same level of proficiency in English. Their level of proficiency was assessed using an standardized placement and a proficiency exam of the university respectively.

\subsection{Procedure}

The two groups were assigned to two different classes. In Advanced Reading I classes, the learners in both classes were instructed to form 4-person literature circles assigning each member four different roles; culture-connector, questioner, vocabulary builder, and summarizer. The roles in each circle were rotated so as to have each group member accommodate every role once over the course off the sessions. The literature circle presentations lasted for 14 weeks, 2 hours a week. The focus of the study was on the questioning types of the questioners in their circles in which they were expected to ask a range of generally around three to four questions aimed at engaging other circles in conversations and debates. The students were expected to read the assigned texts and ask the questions based on the content of the readings. The different types of the questions asked by the questioners in each circle of the groups were analyzed in order to investigate whether there was a divergence between the two groups.

\section{Results and discussion}

In order to answer the first research question, a sample t-test was conducted to examine whether the questioning types (i.e., product, choice, process, and metaprocess) of students who had directly passed the proficiency exam were different from the ones who had studied at the preparatory school before they entered their relevant departments.

Table 1. T-Test results of both first and second group questioning types

\begin{tabular}{lllllll}
\hline & & F & Sig. & t & df & Sig. (2-tailed) \\
\hline Product & Equal variances assumed & .564 & .455 & -2.083 & 70 & .041 \\
& Equal variances not assumed & & & -2.076 & 68.101 & .042 \\
\multirow{2}{*}{ Choice } & Equal variances assumed & \multirow{2}{*}{1.539} & .219 & 2.224 & 70 & .029 \\
& Equal variances not assumed & & & 2.209 & 64.564 & .031
\end{tabular}




\begin{tabular}{lllllll} 
Process & Equal variances assumed & 2.253 & .138 & .900 & 70 & .371 \\
\multirow{3}{*}{ Metaprocess } & Equal variances not assumed & & & .890 & 59.195 & .377 \\
& Equal variances assumed & .633 & .429 & -.087 & 70 & .931 \\
& Equal variances not assumed & & & -.087 & 68.914 & .931
\end{tabular}

The results obtained from the $t$-test run (Table 1) indicated that there was not a significant difference between the scores of the first group and the second group in terms of using the product questioning type $t(70)=-2.083, p<.41$ and the choice questioning type $t(70)=2.224, p<.029$. Nor was there any significant difference the two groups while using process $t(70)=.900, p<.371$ and metaprocess questioning types $t(70)=-.087, p<.931$.

The second research question attempted to investigate whether the gender of the learners might have a significant role in their preference for asking certain question types. There were two categorically independent and four continuous dependent variables in this study: students and gender and four question types, respectively. To analyze the data, a two-way MANOVA was conducted. Table 2 (between-subjects factors) shows the number of students falling in each subcategory of independent variables.

Table 2. Number of students falling in each Subcategory

\begin{tabular}{cccc}
\hline & & Value Label & $\mathrm{N}$ \\
\hline Students & 1.00 & Group 1 & 37 \\
& 2.00 & Group 2 & 35 \\
Gender & 1.00 & Male & 19 \\
& 2.00 & Female & 53 \\
\hline
\end{tabular}

Table 3 presents a cross section of the dependent and independent variables' descriptive statistics with the mean and standard deviation of each question type in the subcategories of independent variables.

Table 3. Descriptive statistics of the subgroups and totals

\begin{tabular}{l|llccc}
\hline & Students & Gender & Mean & Std. Deviation & N \\
\hline Product & Group 1 & Male & 9.2000 & 1.93218 & 10 \\
& & Female & 8.7037 & 1.68283 & 27 \\
\cline { 2 - 5 } & Group 2 & Male & 10.1111 & 1.53659 & 9 \\
& & Female & 9.6154 & 2.07994 & 26 \\
\hline Choice & Group 1 & Male & 2.6000 & .96609 & 10 \\
& & Female & 3.4444 & .97402 & 27 \\
\cline { 2 - 5 } & Group 2 & Male & 3.1111 & 1.36423 & 9 \\
& & Female & 2.4231 & 1.27037 & 26 \\
\hline Process & Group 1 & Male & 4.8000 & 1.13529 & 10 \\
& & Female & 4.4444 & 1.18754 & 27 \\
\cline { 2 - 5 } & Group 2 & Male & 3.4444 & .72648 & 9 \\
& & Female & 4.5000 & 1.90263 & 26 \\
\hline meta-process & Group 1 & Male & 2.5000 & .84984 & 10 \\
& & Female & 2.5185 & 1.08735 & 27 \\
\cline { 3 - 5 } & Group 2 & Male & 2.3333 & 1.41421 & 9 \\
& & Female & 2.5385 & 1.06699 & 26 \\
\hline
\end{tabular}

Testing MANOVA assumptions 
1. Equality of covariance matrices: Box's test of equality of covariance matrices tests the null hypothesis that the observed covariance matrices of the dependent variables are equal across groups. The value of Sig in this table should not be less than .001.As can be seen, this assumption was met.

Table 4. Box's test of equality of covariance matrices

\begin{tabular}{lr}
\hline Box's M & 21.584 \\
F & .938 \\
df1 & 20 \\
df2 & 2986.848 \\
\hline Sig. & .537 \\
\hline
\end{tabular}

2. Outliers: Both Mahalanobis and Cook provide distance parameters that encompass two tests examining data for outliers and multivariate normality. Mahalonobis' test combines all data points in dependent variables and measures their distances from a centroid. The critical value for a MANOVA test with four dependent variables is 18.47. Values larger than this point to the existence of outlier(s). The value for Cook's distance should preferably be below 1. According to Field (2009), Cook's distance "is a measure of the overall influence of a case on the model" (P. 217). Fortunately, in both tables Cook's distance is much smaller than 1, meaning that outliers have not been exerting too much influence on the overall model. Also, examining the Mahal values calculated for this MANOVA revealed that there were only two outliers in the sample and although their scores would adversely affect the result, with the small Cook's distances, the magnitude of the effect would not be very large.

Table 5. Mahal and Cook's distance calculated for students

\begin{tabular}{lccccc}
\hline & Minimum & Maximum & Mean & Std. Deviation & N \\
\hline Mahal. Distance & .372 & 29.618 & 3.944 & 4.971 & 72 \\
Cook's Distance & .000 & .253 & .017 & .033 & 72 \\
\hline
\end{tabular}

Table 6. Mahal and Cook's distance calculated for gender

\begin{tabular}{cccccc}
\hline & Minimum & Maximum & Mean & Std. Deviation & $\mathbf{N}$ \\
\hline Mahal. Distance & .372 & 29.618 & 3.944 & 4.971 & 72 \\
Cook's Distance & .001 & .080 & .013 & .016 & 72 \\
\hline
\end{tabular}

3. Linearity: In conducting MANOVA, it is necessary that a degree of straight-line relationship be existent between each pair of dependent variables. From the graph below, it is obvious that this assumption was met to a great extent with only weak correlations between process/product variables showing among males. 

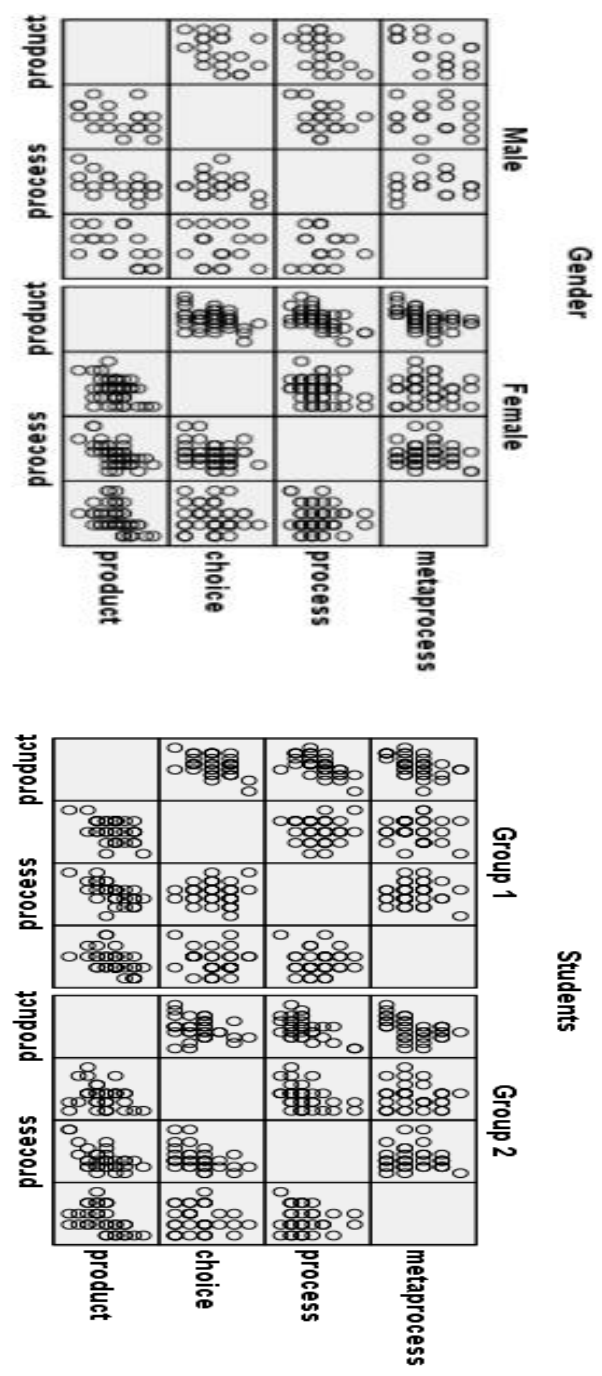

Figure 1. Relationships between dependent variables across gender and students

4. Multicolinarity and singularity: MANOVA works best with moderate correlations between independent variables. When the correlations are very high, this is referred to as multicolinarity and when they are perfect, these are referred to as singularity. Both of these situations undermine the plausibility of running MANOVA. The following table shows the correlations between the dependent variables in this study. Of the 7 possible correlations that can be calculated, the only problematic results are correlations between meta-process and process with $\mathrm{r}=-.060$ and meta-process and choice with $\mathrm{r}=-$ .096 that can be overlooked.

Table 7. Correlations between dependent variables

\begin{tabular}{llrrrr}
\hline & & product & choice & process & Meta-process \\
\hline Product & Pearson Correlation & 1 & $-.376^{* *}$ & $-.592^{* *}$ & $-.483^{* *}$ \\
& Sig. (2-tailed) & & .001 & .000 & .000 \\
& $\mathrm{~N}$ & 72 & 72 & 72 & 72 \\
\hline Choice & Pearson Correlation & $-.376^{* *}$ & 1 & $-.256^{*}$ & -.096 \\
& Sig. (2-tailed) & .001 & & .032 & .429 \\
& $\mathrm{~N}$ & 72 & 72 & 72 & 70 \\
\hline Process & Pearson Correlation & $-.592^{* *}$ & $-.256^{*}$ & 1 & -.060 \\
& Sig. (2-tailed) & .000 & .032 & & .624 \\
& $\mathrm{~N}$ & 72 & 72 & 72 & 72 \\
\hline
\end{tabular}




\begin{tabular}{|c|c|c|c|c|c|}
\hline \multirow[t]{3}{*}{ meta-process } & Pearson Correlation & $-.483^{* *}$ & -.096 & -.060 & 1 \\
\hline & Sig. (2-tailed) & .000 & .429 & .624 & \\
\hline & $\mathrm{N}$ & 72 & 72 & 72 & 72 \\
\hline
\end{tabular}

5. Equality of error variances: This assumption requires a non-significant error variance value for dependent variables across groups. If this assumption is violated, a more conservative alpha level, i.e., .025 or .01 should be used in interpreting the significance of difference. In this study, as is evident in Table 8, except for one dependent variable, that is, process, the error variances are all non-significant.

Table 8. Equality of error variances

\begin{tabular}{lllll}
\hline & F & df1 & df2 & Sig. \\
\hline Product & .666 & 3 & 70 & .576 \\
Choice & .601 & 3 & 70 & .616 \\
Process & 3.452 & 3 & 70 & .021 \\
meta-process & 1.672 & 3 & 70 & .181 \\
\hline
\end{tabular}

\section{Results of MANOVA}

There are two important tables in MANOVA, the multivariate tests table and the between subjects effects table. The first of these tables tell us if first, an interaction effect exists between the independent variables and second, if the main effects of the independent variables are significant. Table 8 below is the multivariate tests table.

Table 9. Multivariate tests of interaction and main effects

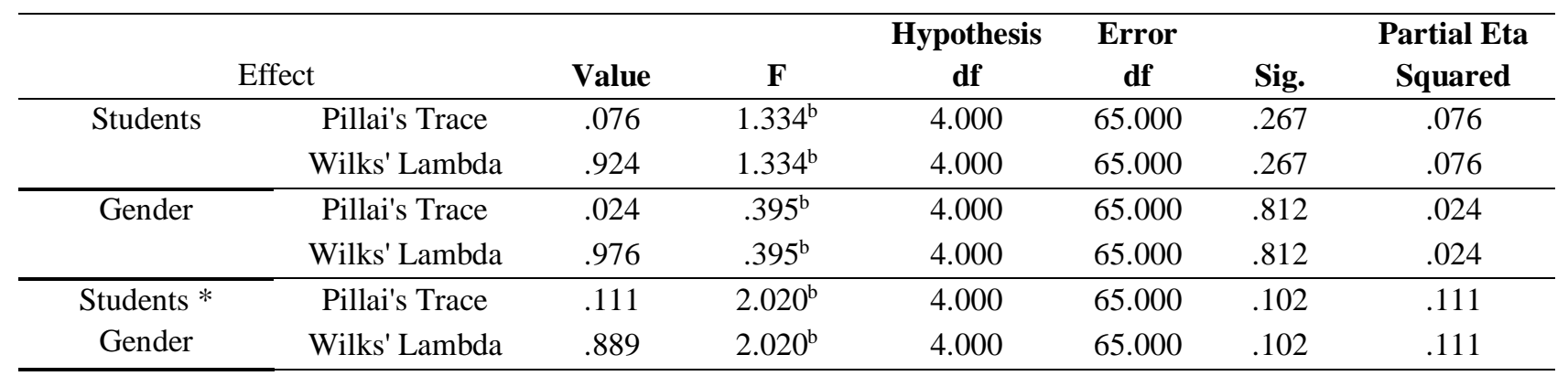

Table 9 indicates that neither is there an interaction effect between the independent variables nor the grouping and gender of the students in this study have exerted any significant influence on the participants' questioning types. Therefore, the answers to both questions: "does gender play a significant role in the participants' preference for questioning types" and "are the questioning types of the students in different groups, as defined in this study, different from each other" are NO. Table 10 presents a more detailed account of the values calculated for the question types across independent variables. 
Table 10. Between subjects effects

\begin{tabular}{llcccccc}
\hline Source & $\begin{array}{c}\text { Type III } \\
\text { Dependent }\end{array}$ & $\begin{array}{c}\text { Sum of } \\
\text { Squares }\end{array}$ & df & $\begin{array}{c}\text { Mean } \\
\text { Square }\end{array}$ & F & Sig. & $\begin{array}{c}\text { Partial Eta } \\
\text { Squared }\end{array}$ \\
\hline Students & product & 11.593 & 1 & 11.593 & 3.365 & .071 & .047 \\
& choice & .908 & 1 & .908 & .700 & .406 & .010 \\
& process & 5.897 & 1 & 5.897 & 2.804 & .099 & .040 \\
& Meta-process & .075 & 1 & .075 & .063 & .803 & .001 \\
\hline Gender & product & 3.434 & 1 & 3.434 & .997 & .322 & .014 \\
& choice & .085 & 1 & .085 & .066 & .798 & .001 \\
& process & 1.710 & 1 & 1.710 & .813 & .370 & .012 \\
& Meta-process & .175 & 1 & .175 & .145 & .704 & .002 \\
\hline
\end{tabular}

The last step in conducting a MANOVA is to have a look at the means and standard deviations of the independent variables across the dependent variable(s). Tables 11 and 12 below show us such pieces of information.

Table 11. Means and standard deviations of questioning types across groups

\begin{tabular}{lllccc}
\hline \multirow{3}{*}{ Dependent Variable } & Students & Mean & Std. Error & \multicolumn{2}{c}{ 95\% Confidence Interval } \\
\cline { 5 - 6 } Product & Group 1 & 8.952 & .344 & 8.266 & 9.637 \\
\cline { 2 - 6 } & Group 2 & 9.863 & .359 & 9.147 & 10.579 \\
\hline Choice & Group 1 & 3.022 & .211 & 2.601 & 3.443 \\
\cline { 2 - 6 } & Group 2 & 2.767 & .220 & 2.327 & 3.207 \\
\hline Process & Group 1 & 4.622 & .268 & 4.087 & 5.158 \\
\cline { 2 - 6 } & Group 2 & 3.972 & .280 & 3.413 & 4.532 \\
\hline Meta-process & Group 1 & 2.509 & .203 & 2.104 & 2.914 \\
\cline { 2 - 6 } & Group 2 & 2.436 & .212 & 2.013 & 2.859 \\
\hline
\end{tabular}

Table 12. Means and standard deviations of questioning types across gender

\begin{tabular}{cccccc}
\hline \multirow{3}{*}{ Dependent Variable } & Gender & Mean & Std. Error & Lower Bound & Upper Bound \\
\hline \multirow{2}{*}{ Product } & Male & 9.656 & .426 & 8.805 & 10.506 \\
\cline { 2 - 6 } & Female & 9.160 & .255 & 8.651 & 9.668 \\
\hline \multirow{2}{*}{ Choice } & Male & 2.856 & .262 & 2.333 & 3.378 \\
\cline { 2 - 6 } & Female & 2.934 & .157 & 2.621 & 3.246 \\
\hline \multirow{2}{*}{ Process } & Male & 4.122 & .333 & 3.457 & 4.787 \\
\cline { 2 - 6 } & Female & 4.472 & .199 & 4.075 & 4.870 \\
\hline \multirow{2}{*}{ Meta-process } & Male & 2.417 & .252 & 1.914 & 2.919 \\
\cline { 2 - 6 } & Female & 2.528 & .151 & 2.228 & 2.829 \\
\hline
\end{tabular}

In Tables 11 we can identify which group of the students had the higher score in terms of the question types. Table 12 presents the same kind of information in relation to gender. These pieces of information are not retrievable from the preceding tables. 


\section{Discussion}

As Doherty (2017, p. 1) maintains, questioning "challenges levels of thinking and informs whether students are ready to progress with their learning". The findings regarding the variety of questions being asked by the learners in their oral communication classes indicate that studying at a preparatory school has not seemingly been helpful in terms of developing the level of thinking of learners, as their questioning show not to differ terribly from those having not received any English preparatory education at university. According to Doherty (2017), questions that inquire for deeper processing of meaning further critical thinking skills and more cognitive processing capabilities, such as problem solving, and encourage the types of flexible learners and critical thinkers that are needed in the $21^{\text {st }}$ century. With the growing emphasis on shifting learning responsibility and autonomy to the students in language classes over the last years, the issue of questioning in the classroom also needs to be reconsidered.

In a study conducted in order to examine how questioning was treated by EFL instructors and learners in the classroom, Rezvani and Sayyadi (2015) indicated that the learners hardly made any attempt to formulate English questions regardless of their proficiency levels, and often appeared anxious and relied on their first language when they were to raise questions. Rezvani and Sayyadi (2015) also found that there was a failure on the part of the instructors' forms of behavior, as they hardly intended to enhance the learners' capacity in asking English questions. As a result, the primary concern of teachers, as Kumaravadivelu (2003, p. 20) forwards, must be to elicit a "depth of critical thinking", rather than the "breadth of content knowledge". As for questioning, rather than asking questions touching the breadth of content knowledge, students should be involved in the process of questioning for the sake of challenging each other by requesting more critical responses. In conclusion, rather than seeing the teacher as the dominant questioner and considering questioning as the responsibility of the teacher alone to create learning opportunities in the classroom, more responsibilities need to be assigned to learners to actively participate in their own language development and to shape their own path. In so doing, learners should be prompted to develop their own critical thinking abilities to be able to ask critical questions.

Pizzini and Shepardson (1991) believe that the number and kinds of questions asked by students can be significantly influenced by thoughtful lesson structure and conscious teaching strategies. In order to foster critical thinking of learners, and pave the way for asking more critical questions, the cognitive process dimension of Bloom's Revised Taxonomy put forward by Anderson et al (2001) ought to be integrated into teaching methodology. Simply put, while giving feedback to the questioning of the students, the teacher may integrate all levels of the cognitive process: knowledge, comprehension, application, analysis, evaluation and creation. In the paper, How to Ask Questions that Prompt Critical Thinking, open educational resources of University College Dublin, fully accounts for how all levels of the cognitive process of Bloom's Revised taxonomy can be integrated in questioning:

- Knowledge exhibits previously learned material by recalling facts, terms, basic concepts and answers. With the focus on knowledge, to exemplify, the teacher can teach the learners to ask 'what is...?' or when did... happen?' or other question constructs trying to elicit responses about the previously learned materials. Most of the questions asked with the focus on knowledge would resemble Hugh Mehan's product questions.

- Comprehension demonstrates understanding of facts and ideas by organizing, comparing, translating, interpreting, giving descriptions and stating main ideas. So the question constructs for this level of cognitive process would be, say, 'How would you compare or contrast...?' and 'What facts or ideas show...?'

- Application is a level in which the focus is on solving problems by applying acquired knowledge, facts, techniques and rules in a different way. Examples of questions with the 
involvement of application might include such question types as 'What might have happened if...?' and 'What approach would you use to...?'

- Analysis examines and breaks information into parts by identifying motives or causes; making inferences and finding evidence to support generalizations. Some question constructs may include 'What inference can you make from...?' and 'How would you categorize...?'

- Evaluation presents and defends opinions by making judgments about information, validity of ideas or quality of work based on a set of criteria. 'Which do you think is better...?', 'What was the value or importance of ... in ...?', and 'What would you have recommended if you had been

...?' are some questioning constructs to be used while asking critical questions.

- Finally, creation/ synthesis compiles information together in a different way, by combining elements in a new pattern or proposing alternative solutions. 'What might have happened if...?' and 'Can you propose an alternative interpretation to that of...?' are two well formulated constructs of question which possess a focus on the creation level of the cognitive process.

In conclusion, the cognitive process dimension of Bloom's Revised Taxonomy must be integrated in language classrooms in order to equip learners with various techniques of asking questions which focus on different levels of the cognitive process. In a classroom where the learners are good questioners, the learning process will be surely accelerated. In research, we can expect to see further work that investigates the effectiveness of the questions being asked by teachers and students in classroom. In addition, as aforementioned, despite the abundant number of studies on teacher questioning, seemingly few studies have been conducted to examine the students' questioning in the classroom. Therefore, research also needs to examine more closely the students' questioning and its frequency while interacting in speaking classes.

\section{References}

Almeida, P., \& Neri de Souza, F. (2010). Questioning profiles in secondary science classrooms. International Journal of Learning and Change, 4(3), 237-251.

Almeida, P., Pedrosa de Jesus, H., \& Watts, M. (2008). Developing a mini-project: students' questions and learning styles, The Psychology of Education Review, 32(1), 6-17.

Anderson, L. W., Krathwohl, D. R., Airasian, P. W., Cruikshank, K. A., Mayer, R. E., Pintrich, P. R., Raths, J., \& Wittrock, M. C. (2001). A taxonomy for learning, teaching, and assessing: A revision of Bloom's Taxonomy of Educational Objectives. New York: Longman.

Arslan, M. (2006). The role of questioning in the classroom. Hasan Ali Yücel Journal of Education, 2, 81-103.

Bajrami, L. (2015). Teacher's new role in language learning and in promoting learner autonomy. Procedia-Social and Behavioral Sciences, 199, 423-427.

Chatelier, S., \& Rudolph, S. (2018). Teacher responsibility: shifting care from student to (professional) self?, British Journal of Sociology of Education, 39(1), 1-15.

Chin, C. (2007). Teacher questioning in science classrooms: Approaches that stimulate productive thinking. Journal of Research in Science Teaching, 44(6), 815-843.

Cook-Sather, A. (2010). Making Space for Learning. An essay review of what the best college teachers do. Curriculum Inquiry, 40(2), 283-293. 
Coutinho, M., \& Almeida, P. (2014). Promoting student questioning in the learning of natural sciences. Procedia-Social and Behavioral Sciences, 116, 3781-3785.

Doherty, J. (2017). Skillful questioning: the beating heart of good pedagogy. Retrieved February 5, 2018, from https://impact.chartered.college/article/doherty-skilful-questioning-beating-heartpedagogy/

Floyd, W. D. (1960). An analysis of the oral questioning activities in selected Colorado classrooms. Colorado State College, Colorado, USA.

Graesser, A., \& Olde, C. (2003). How does one know whether a person understands a device? The quality of the questions the person asks when the device breaks down. Journal of Educational Psychology, 95, 524-536.

Graesser, A., \& Person, N. K. (1994). Question asking during tutoring. American Educational Research Journal, 31(1), 104-137.

Harlen, W., \& Qualter, A. (2004). The Teaching of Science in Primary Schools. London: David Fulton Publishers.

Hastings, S. (2003). Questioning, TES Newspaper, 4 July. Retrieved February 5, 2018, from https://www.tes.co. uk/article.aspx?storycode $=381755$

Heritage, M., \& Heritage, J. (2013). Teacher questioning: The epicenter of instruction and assessment, Applied Measurement in Education, 26(3), 176-190.

Kumaravadivelu, B. (2003). Beyond methods: Macrostrategies for language teaching. Yale University Press.

Long, M., \& Sato, C. (1983). Classroom foreigner talk discourse: Forms and functions of teachers' questions. In H. Seliger \& M. Long (Eds.), Classroom-oriented Research in Second Language Acquisition (268-285). Rowley, Mass.: Newbury House.

Martinho, M., Almeida, P. \& Teixeira-Dias, J.J.C. (2012). Students' questions in higher education chemistry classes according to their gender. Procedia-Social and Behavioral Sciences, 47, 835840 .

Nunan, D. (1989). Understanding language classrooms. Hemel Hempstead: Prentice Hall.

Pizzini, E. L., \& Shepardson, D. P. (1991). Student questioning in the presence of the teacher during problem solving in science, School Science and Mathematics, 91, 348-352.

Qashoa, S. H. (2012). Effects of teacher question types and syntactic structures on EFL classroom interaction. The International Journal of Social Sciences, 7(1), 52-62.

Rezvani, R., \& Sayyadi, A. (2015). Instructors' and learners' questioning: A case of EFL classroom discourse in Iran, The Journal of Teaching Language Skills, 7(3), 141-164.

Shomoossi, N. (2004). The effect of teachers' questioning behavior on EFL classroom interaction: A classroom research study. The Reading Matrix, 4(2), 96-104.

Willis, D., \& Willis, J. (2007). Doing task-based teaching. Oxford: Oxford University press.

$\mathrm{Wu}$, K. (1993). Classroom interaction and teacher questions revisited. RELC Journal, 24(2), 49-68.

Zoller, U., Tsaparlis, G., Fatsow, M., \& Lubezky, A. (1987). Student self-assessment of higher-order cognitive skills in college science teaching, Journal of College Science Teaching, 27, 99-101. 


\section{İngilizce öğretmenliği öğrencileri arasında soru tiplerinin incelenmesi}

\section{$\ddot{O} \mathbf{z}$}

Bu çalışmanın amacı, iki grup İngilizce Öğretmenliği Bölümü 1.sınıf öğrencilerinin işbirlikçi öğrenmenin temelini oluşturan soru sorma tekniğini kullanırken seçtikleri ve sordukları soru tiplerini incelemektir. Çalışmaya katılan birinci gruptaki 37 öğrenci hazırlık muafiyet sınavında başarılı olmuştur. Çalışmaya katılan diğer grup ise bir yıllık hazırlık programına devam eden öğrencilerden oluşmaktadır. Çalışmada iki grupta yer alan öğrencilerin her aktivite için seçtikleri soru çeşitleri incelenmiştir. Çalışmanın sonuçları hazırlık muafiyet sınavını geçerek 1.sınıfta eğitime başlayan ve 1 yıllık hazırlık programını tamamlayarak 1.sınıfta eğitime başlayan iki grup arasında kullanılan soru çeşitleri bakımından fark olmadığını göstermiştir. Buna ek olarak, çalışmada cinsiyete dayalı bir fark da bulunmamıştır. Her iki grupta da en sık kullanılan soru çeşidi sonuç sorusu iken en az kullanılan soru çeşidinin gerekçe soruları olduğu sonucu elde edilmiştir.

Anahtar sözcükler: Seçim sorusu; sonuç sorusu; sebep sorusu; gerekçe sorusu; çalışma grupları

\section{AUTHOR BIODATA}

Aynur Kesen Mutlu is an assistant professor of English language teaching, and the head of the ELT department at Istanbul Medipol University. Her research interests include literature and language teaching, EFL, and teacher education.

Mehdi Solhi Andarab is an assistant professor of English language teaching at Istanbul Medipol University. He received his doctorate degree in English Language Education from Istanbul University. He worked as an instructor of English language at Bahçeşehir University and Istanbul Medipol University from 2012 to 2017. As of 2017, he started as an assistant professor in the department of ELF at School of Education, Istanbul Medipol University. His research interests include Applied Linguistics, English as a lingua franca, cultural studies, coursebooks, and teaching writing. 